\title{
Partisan and Apportionment Bias In Creating A Predominant Party System
}

\begin{abstract}
A B S T R A C T
Moving beyond the analytical characteristics of apportionment methods or election systems, this article focuses on their outcomes in practice. We illustrate how apportionment and partisan biases working with a high threshold created an electoral environment conducive to the establishment of a predominant party system. We use the historical example of the Turkish experience. We trace the historical development of disproportionality for the entire multi-party elections for the 1950-2015 period. Focusing on the five most recent elections of this period since 2002, we demonstrate how the biases introduced by the apportionment method in use and the $10 \%$ threshold have advantaged the leading Justice and Development Party (Adalet ve Kalkınma Partisi, AKP). Our study suggests that a partisan bias favoring AKP still continues to exist at a lower level even after correcting the apportionment and the threshold biases. We underline how these biases form the foundation for a conservative over-representation and emphasize the path-dependent dynamics that keep challengers to the AKP away from the electoral scene, effectively helping to continue its hegemonic position in the system.
\end{abstract}

Keywords: Apportionment, partisan bias, proportional representation systems, predominant parties, Turkey. 


\section{Partisan and Apportionment Bias In Creating A Predominant Party System}

\section{Introduction}

The representative capacity of political institutions is indispensable for legitimacy and effective governance in modern democracies. Parliaments bring together a number of legislators who are expected to represent a much larger number of individual citizens. A system of representation first relies on a limited number of representatives who are linked to geographic constituencies in accordance with their populations via an apportionment system. For each of the geographic units, citizen support for candidates or parties is transformed into an earlier determined number of seats in each geographic constituency via an election system. The analytical basis of representation at both levels is the same one of linking many people to the much fewer number of either seats or party representatives. Given the distribution of people across geographic units or behind different political parties, seat distributions in a representative assembly could be significantly different under different apportionment or election systems.

Although characteristics of apportionment methods or election systems are well-known, their outcomes in practice are relatively scantly studied. ${ }^{1}$ Our objective here is to offer an indepth analysis of a proportional representation system and exhibit the nature and sources of the partisan bias in this system. Given the logic of a proportional representation system that aims to allocate seats in accordance with votes a party receives, one might be tempted to think that there should be no partisan bias in such systems. However, it is known that the D'Hondt method, for example, favors the larger parties at the expense of the smaller parties (Rae et al., 1971; Schuster et al. 2003). Malapportionment effects that overlap with geographic

\footnotetext{
1 For analytical treatments see Schwingenschlögl \& Drton (2004). Balinski \& Young (2010), Pukelsheim (2014), Schuster et al. (2003) and Taagepera, R., \& Shugart (1989) provide empirical perspectives as well.
} 
distributional differences of parties' electoral support could also conceivably create a systematic bias favoring one party or electoral tradition over others. The Turkish party system provides an excellent case to study partisan bias in a proportional representation system. We know from past work of Çarkoğlu and Erdoğan (1998) that malapportionment is significant in Turkey and $10 \%$ threshold not only restricts regional parties' representation, but it effectively also brings about a minimum size effect into the system. ${ }^{2}$ Both factors are likely to create and maintain partisan biases despite proportional representation in use.

We argue that the peculiar historical constellation of these biases in the apportionment as well as the election system in Turkey prepared a vastly advantageous ground for the Justice and Development Party (Adalet ve Kalkınma Partisi, AK Parti or AKP) capturing the executive office and then developing itself into a predominant party over the course of five general elections between 2002 and 2015. ${ }^{3}$ Although the tenure of AKP started with a lot of optimism for Turkey's long-standing conflicts with its Kurdish minority, for its membership quest in the $\mathrm{EU}$, and for its resolution of economic inequalities, recent literature has become more pessimistic in its evaluations which emphasize the rising trend of democratic backsliding in the country. ${ }^{4}$ We show in our analyses how the partisan bias and the apportionment system have created the opportunity for the establishment of an electoral predominance for AKP and hence

\footnotetext{
2 The 10\% threshold was imposed in the aftermath of 1980 military coup in June 1983 before the November 1983 general elections. This threshold requires that a party receives at least $10 \%$ of the valid votes in order to gain representation in the parliament.
}

${ }^{3}$ Although we acknowledge the authoritarian tendencies in the AKP rule, we follow Sartori (1976, pp. 204-211) that "the hegemonic party neither allows for a formal nor a de facto competition to power. Other parties are permitted to exist, but as second class, licensed parties ... the possibility of a rotation in power is not even envisaged." The case of AKP appears somewhat distant to fit under this category especially for the period under study and hence we use the term predominant party throughout our discussion. See Schedler (2013: pp.191-194) for an alternative definition of hegemonic systems. Sartori (1976: pp. 171-192) defines a predominant party system as one in which the major party wins significantly stronger majority of voters over its competitors for at least three consecutive elections. See Çınar (2016) and Gümüşcü (2013) on AKP's rise to electoral dominance.

${ }^{4}$ See Esen and Gümüşçü (2016), Akkoyunlu and Öktem (2016), Somer (2016) on the democratic backsliding in Turkey during the AKP era. 
paved the way towards its control over the entire party system. We underline that corrections of these biases would have led to different election outcomes and make a case for electoral reform towards establishing a better representative democracy. Our analyses suggest that the proportional representation systems in practice could lead to widely disproportional results that create opportunities for some political parties to exploit these biases to their advantage and stay in power as a predominant party for long periods of time.

Below we first describe the Turkish apportionment and election system and show how the representational bias has developed over the entire multi-party election period of 1950 to 2015 and how it was further strained during the tenure of AKP. We explore the partisan bias in the system, simulate election results by correcting the apportionment bias, and demonstrate how these results would have created an entirely different party system in the country-a party system that is more competitive and representative of the citizens of Turkey. As such, we contribute to the newly emerging literature on electoral authoritarianism and illustrate that representational biases are partially responsible for the emergence and endurance of these regimes. $^{5}$

\section{Malapportionment, Disproportionality, and Bias in Turkish Elections}

Since the first competitive and fair elections of 1950, Turkish voters have gone to the polling places in eighteen general elections with participation rates ranging between the lowest of $64.3 \%$ in 1969 and the highest of $93.3 \%$ in 1987.6 The registered voters back in 1950 were

\footnotetext{
5 On electoral authoritarianism see Morse (2012) and Schedler (2013).

6 Throughout the ensuing discussions we will use the official election results data from the Turkish Republic Higher Election Council (Yüksek Seçim Kurumu, YSK) available at http://www.ysk.gov.tr/tr/milletvekili-genel-secim-arsivi/2644 (retrieved in February 2018). All ensuing seat distribution calculations and simulations for partisan bias are done with spreadsheet applications developed by the author(s). We will take the 1950 election as the start of the freely competitive party system in Turkey. Although several parties competed in the 1946 election, it is generally accepted that this election was subject to manipulations by the incumbent Republican People's Party (Cumhuriyet Halk Partisi, CHP) (Eroğul, 1990, pp. 15-17).
} 
about 8.8 million and reached nearly 57 million in November 2015 general elections. Although in principle these millions of voters are all equally participating in elections, in practice the value of their vote is far from being equal. Voters are typically divided into numerous geographical units that form the basis of representation. Examples are states in the U.S.A., countries in the European Parliament, and provinces ${ }^{7}$ in the Turkish Grand National Assembly (Türkiye Büyük Millet Meclisi, TBMM). Ideally, we expect a typical voter across geographical units to "share" a representative in the parliament with roughly the same number of neighbors. This requires the number of representatives obtained by each geographical unit to be approximately commensurate with that unit's population share. Otherwise, the fundamental principle of equal vote value is violated and hence malapportionment arises.

As an example from the Turkish case, in 1950 elections there were across all provinces 43,013 people on average for each one of the 487 representatives in the TBMM. However, in the Aegean coastal province of Aydın for instance, there were 47,952 people for each representative, but only 30,252 people were registered in the Black Sea coastal province of Rize for one representative. In 2015 general elections, on average 143,166 people were registered across all provinces for each one of the 550 representatives. However, for every representative from the eastern Black Sea province of Bayburt, there were only 39,275 people, whereas in Istanbul every 166,562 people had one representative. Accordingly, the citizens of Istanbul shared their representatives in the TBMM with approximately 4.2 times as many people as did those in Bayburt. Since each representative has one vote in the TBMM, a typical individual in Bayburt had 4.2 times as much representation.

\footnotetext{
7 The three largest metropolitan provinces, i.e. İstanbul, Ankara and İzmir, have had sub-provincial election regions since the general election in 1995. However, all members of the parliament elected from different sub-provinces become the provincial representatives in the TBMM.
} 
The example of representational disparity found in the cases of Bayburt and Istanbul is not unique. Fig. 1 and Fig. 2 summarize the whole range of representational disparities across all elections during $1950-2015$ period. ${ }^{8}$ In the three elections of the 1950 s, the size of the TBMM was linked to the population size. For every 40 to 55 thousand people one representative was allotted and for every additional 40 thousand people, an additional seat was created in the TBMM. Accordingly, the size of the TBMM grew from 487 seats in 1950 to 610 in 1957. Such an arrangement kept the mean population required for each seat in the TBMM low compliant with the law. It also substantially reduced the deviation around that mean population.

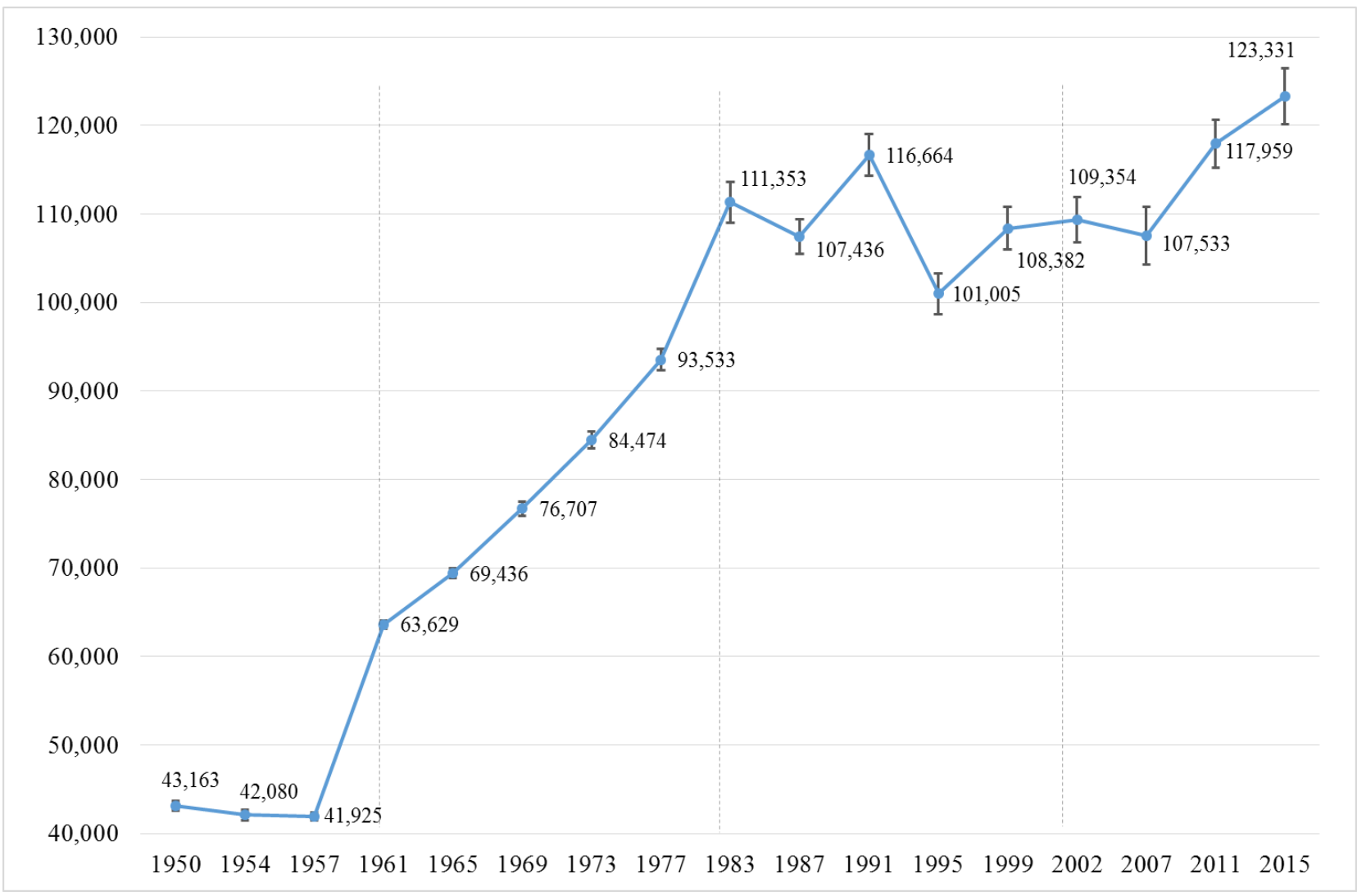

Fig. 1. Mean population required for each seat in the TBMM, 1950-2015.

\footnotetext{
${ }^{8}$ Both figures 1 and 2 do not differentiate between the two elections in June and November of 2015 since these elections relied on one and the same seat distribution across the provinces or election districts.
} 
Fig. 2 shows the ratio of the highest population required per seat to the lowest across all provinces over the 1950-2015 period. In 1950 the highest population required per seat was observed in the Eastern Anatolian province of Muş with two seats and the lowest population required per seat was observed in the Eastern Black Sea province of Rize with six seats. The ratio of 1.77 indicates that Muş residents had to share their representatives with about $77 \%$ more people compared to Rize residents. In all other provinces, the representational discrepancy is less than this ratio. It is also worthy of note that during the 1950s the representational bias appears to work against the Eastern Anatolian provinces; the largest wasted population in these years are observed in Muş, Bitlis, and Hakkâri, while beside Rize we have Kocaeli and Bilecik both from the eastern Marmara region in the western part of the country as the provinces with the least population per seat allocated to the province.

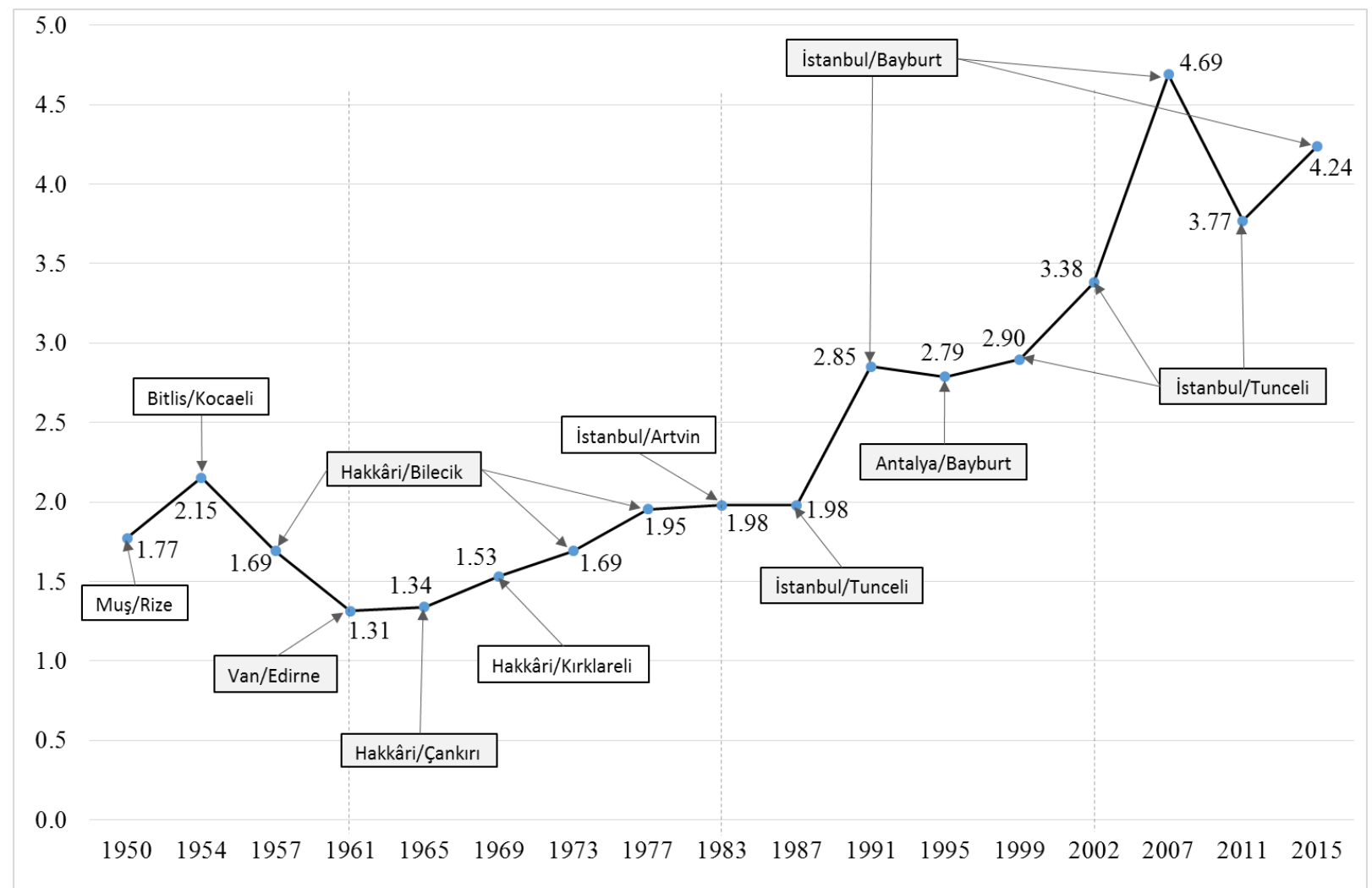

Fig. 2. The ratio of highest over lowest number of registered voters for each seat in the TBMM, 1950-2015. 
The representational crisis of the 1950s was not so much due to the apportionment but rather the election system which used a plurality system with large election districts. For the three general elections in the 1950s, the party that obtained the largest number of votes in a given province won all seats allocated to that province. As such, all votes cast for the parties that came in second or lower did not have any representation or were "wasted". In the aftermath of the 1960 coup, both the apportionment and the election systems were changed to allow better representation. What is known as the Hamilton method was adopted for the apportionment, and the D'Hondt method was adopted to distribute seats to parties in the parliament. ${ }^{9}$ The size of the TBMM was set at 450 seats inevitably lifting the average number of people to be represented by each seat. We see from Fig. 1 that the mean number of people per seat jumped up by about $50 \%$ from 1957 to 1961 election, and given a constant size of the TBMM it continued to rise consistent with the population increase during this period. However, the spread of population per seat (or the standard error of the mean population per seat) across provinces that is an indicator of the representational discrepancies rises slightly, but remains comparable to the 1950s through the end of 1970s.

Fig. 2 shows the spread of representational discrepancy between the largest (indicating the most disfavored province) mean population required per seat to the lowest (indicating the most favored province) mean population required per seat remaining in the range of 30 to 95 percent in the 1960s and 1970s. We again observe that the most disfavored provinces were from Eastern Anatolia; Van in 1961 and Hakkâri between 1965 and 1977. If we took the case of Hakkâri in 1977, we see that its population per seat was 95\% higher than that in Bilecik which had the most favored or lowest population per seat available in that province. In other words, despite changes in the apportionment methods during the first three decades of multi-party

\footnotetext{
${ }^{9}$ See Young (1995) for different apportionment methods and Farrel (2011) on the working of the proportional representation systems.
} 
elections with a total of eight elections, smaller Eastern Anatolian provinces were disfavored while larger Western, Central Anatolian and Eastern Black Sea region provinces were being favored by the apportionment system in place. $^{10}$

The military regime established in the aftermath of the coup of 1980 instituted critical changes in both the apportionment and the election system that increasingly deteriorated the representational equity in the country. The new apportionment system required that each province is allocated a seat irrespective of its population, then the same Hamilton method is applied to the new size of the TBMM set at 400 seats. ${ }^{11}$ The distribution of seats to political parties according to their vote shares in provinces was again done by the D'Hondt method. However, parties that failed to gather at least $10 \%$ of the valid votes nationwide were not granted access to the parliament irrespective of the share they received in a given province. ${ }^{\mathbf{1 2}}$ Hence regional parties without $10 \%$ of the nationwide votes were excluded from the TBMM.

The new apportionment method increasingly raised the disparities between primarily smaller Anatolian provinces and larger western provinces. Fig. 1 shows that disparities between provinces in terms of standard errors around the mean are significantly higher in the post-1980 period compared to earlier periods. Most significant enlargement of representational disparities is observed in the post-2002 period. While the average population per seat in the TBMM grows

\footnotetext{
${ }^{10}$ Is this pattern linked to the Kurdish population in these regions? We separated the 16 provinces where Kurdish population share is larger than 40\% following Mutlu's (1996) calculations and tested in each election year whether these provinces as a group have a significantly different required number of people per seat. We found significantly positive results for 1950, 1969, 1973 and 1977 elections, and negative, yet insignificant results for all elections afterwards. Hence, the apportionment system in use for the pre1980 period indeed appears to disfavor the predominantly Kurdish provinces of Eastern and Southeastern Anatolia. Although this pattern is reversed in later periods, it has lost its statistical significance.

11 The total number of seats in the TBMM was raised back to 450 for the 1987 and 1991 elections and eventually to 550 from 1995 through 2015 general elections.

12 In the first three elections of 1983, 1987 and 1991, in addition to the national thresholds, there was also a local threshold in order for a party to qualify for a seat in the TBMM (see Sabuncu, 2006).
} 
primarily due to population enlargement, the range around that mean grows due to the new method of apportionment favoring smaller and newly created provinces.

Creation of new provinces from gatherings of geographical units around sizeable districts gained momentum in the post-1980 period. These relatively smaller new provinces benefitted from the new apportionment rule that granted them one seat irrespective of their population size. ${ }^{13}$ Fig. 2 demonstrates that this new apportionment method disfavored Istanbul and Antalya the most among other larger metropolitan provinces. The newly created province of Bayburt, older and smaller provinces of Artvin in Eastern Black Sea and Tunceli in Eastern Anatolia appear to have benefitted from the new apportionment rule.

Developments in the seat-vote relationship are best described in a summary form by the Gallagher Index of Disproportionality (GID) which relies on the squared differences between seat and vote shares across all parties in the system. ${ }^{14}$ Fig. 3 below shows the development of disproportionality throughout all elections since 1950 . The peculiar election system of the 1950s with the largest vote-getter winning all seats in large districts yielded the highest disproportionality for the first two elections of that period. In the third 1957 election, the opposition Republican People's Party (Cumhuriyet Halk Partisi, CHP) managed to increase its national vote share to $41.4 \%$, which had been $35.1 \%$ in 1954 and $39.6 \%$ in 1950 elections. This improvement in the third election of the period signifies the increased ability of CHP to collect the whole seat allocation from a few more provinces compared to earlier elections. Thus, the overall disproportionality declined in 1957. Following the introduction of a proportional representation system with the D'Hondt method without any national thresholds for the 1960s and 1970s, we observe relatively low levels of disproportionality in the country.

\footnotetext{
13 All 14 new provinces obtained two or more seats in the first election in which they were allocated seats.

${ }^{\mathbf{1 4}}$ Gallagher Index of disproportionality (GID) $=\sqrt{\frac{1}{2} \sum_{i \in \text { Parties }}\left(\text { Seat } \%_{i}-\text { Vote } \%_{i}\right)^{2}}$
} 


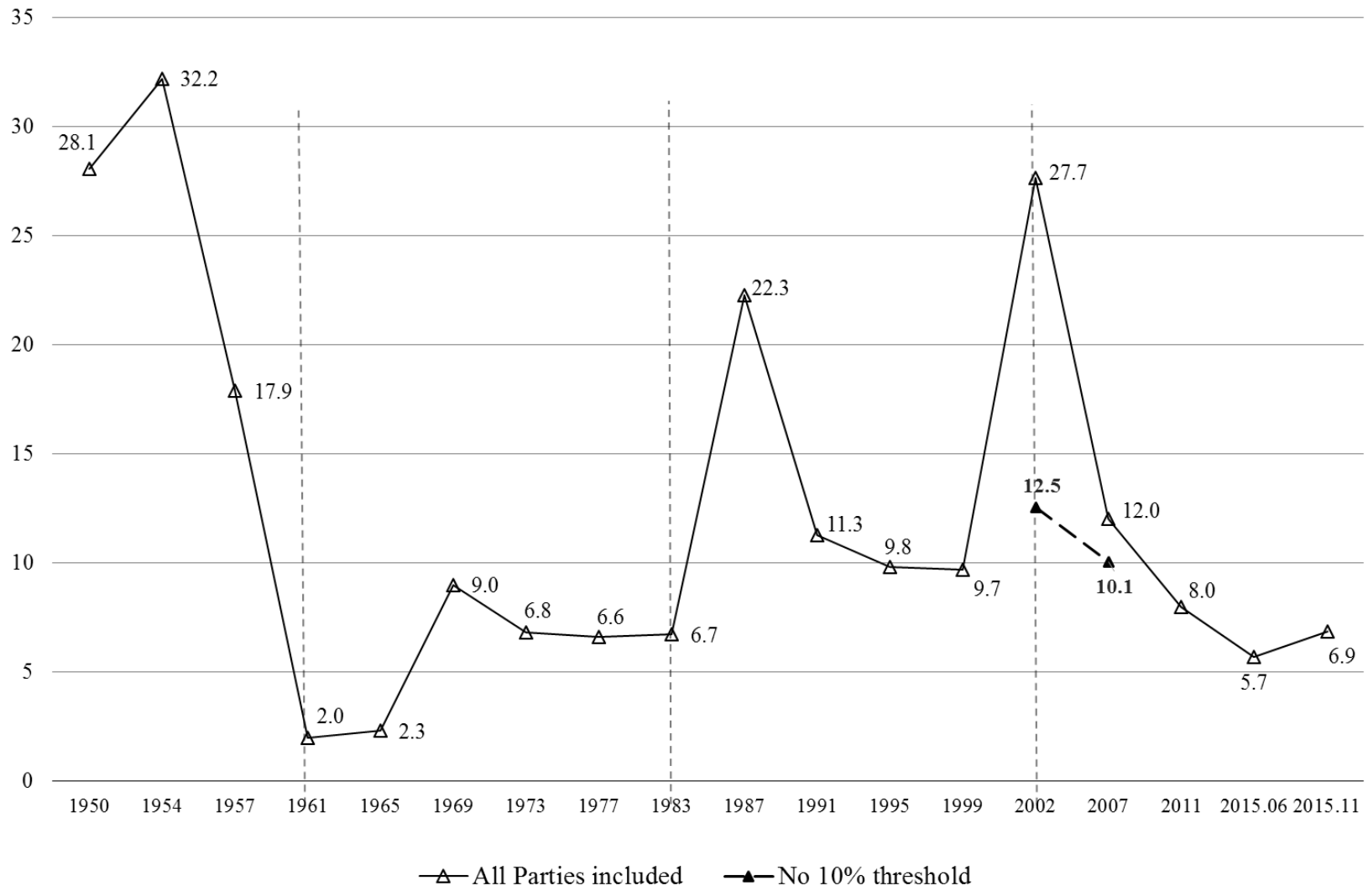

Fig. 3. The Gallagher Index of Disproportionality (GID) for Turkish general election results, 1950-2015.

With the new apportionment system and the $10 \%$ threshold rule put into effect for the first post-coup election in 1983 , we see no dramatic shift in disproportionality due to having only three parties allowed to compete in the elections by the military regime. All three of these parties were above the threshold and the unrepresented vote share was less than two percent. With more parties entering the competition and remaining below the $10 \%$ threshold, the GID rose significantly in 1987 when $18.9 \%$ of the votes could not gain representation in the TBMM. ${ }^{15}$ Again in 2002, a similar peak occurred in the GID with $45.3 \%$ of the votes gaining

\footnotetext{
15 The military regime imposed a 10 year ban to the leadership of political parties of the pre- 1980 period to participate in politics. This ban was lifted by a referendum on September 6, 1987. Since the lifting of the ban was by a very close vote margin of about 75,000 votes the then-ruling Motherland Party (Anavatan Partisi, ANAP) decided to take the country for an early election on November 29, 1987. With the normalization of party competition by the lifting of the ban on party leaders, seven parties participated in the 1987 election and only three remained above the $10 \%$ threshold, thus resulting in a jump of disproportionality.
} 
no representation in the TBMM. With more parties passing the nation-wide electoral threshold in the following elections, the disproportionality index declined first to levels comparable to the 1980s and 1990s, and then to levels reminiscent of the 1960s and 1970s. ${ }^{\mathbf{1 6}}$

An important point to note here concerns the influence of the $10 \%$ threshold upon the disproportionality in the party system. We see in Fig. 3 that when the threshold was not applied the disproportionality scores were significantly lower. Especially in the critical elections of 1987 and 2002 when the threshold was effective in keeping several important parties out of the TBMM, the lifting of the threshold reduced disproportionality by more than $50 \%$. In 1983 , 2011, June 2015 and November 2015 elections, no party that remained below the $10 \%$ threshold had a sufficient number of votes to win a seat. Hence the disproportionality scores are not influenced by the threshold. However, in election years such as 1987, 1995, 1999, 2002 and 2007 when there were parties below the threshold with a sufficient number of votes to win seats in various provinces, the seat distribution in the TBMM would have changed with reflections upon lowering disproportionality scores. In other words, for the post-1980 period, the existing disproportionality that we observe in the Turkish party system is primarily due to the $10 \%$ threshold together with the geographical distribution of electoral support across parties. ${ }^{\mathbf{1 7}}$

\footnotetext{
${ }^{\mathbf{1 6}}$ The fact that wasted votes are in decline should not, however, be taken as an evidence that all electoral preferences find some reflection in the system. Knowing that some parties are likely to remain below the $10 \%$ threshold, many voters may simply cast a strategic vote. They vote not for their first preference, but rather another party of lower level preference that may have some inner factions within it to allow these individual preferences to have some reflection. The fact that following the rise of the AKP, no credible new party has risen in the party system could also be attributed to various barriers in the system. See Çarkoğlu (2002).

${ }^{17}$ For geographic patterns in Turkish election results see Çarkoğlu and Avc1 (2002), Çarkoğlu and Yıldırım (2015), Çınar (2016) and Güvenç and Kirmanoğlu (2009). The overall pattern observed in these studies is that the coastal and larger provinces are politically more competitive and provide a stronger electoral base for the centrist left-wing parties. Eastern and southeastern provinces are base to Kurdish parties, but they are also a base for AKP in the post-2002 era. The remaining inner Anatolian provinces are home to conservative and nationalist party dominance.
} 


\section{Partisan Bias during the Tenure of AKP}

We now focus on diagnosing the partisan bias in the most recent period of 2002-2015 with five general elections that exhibit relatively low system level disproportionality but increasingly worsening representation from the perspective of apportionment. We hence aim to trace election system foundations of the establishment of AKP's establishment of its electoral predominance.

We first adopt three alternative apportionment methods (Jefferson, Hamilton and Webster) and compare the resulting seat distribution with the current method in use. For 2002 and 2007 we present seat distributions for the case of $10 \%$ threshold using all four apportionment methods in comparison to the case when the threshold is hypothetically lifted. Given the distribution of votes across election districts, since none of the below-threshold parties could win a seat when the threshold is lifted, such a comparison is not necessary for the last three elections in June 2011, June 2015 and November 2015.

Our treatment of the partisan bias follows from Brookes' $(1959,1960)$ original analysis of New Zealand elections. To our knowledge, a similar application in a proportional representation system is not available, and the literature is limited to plurality election systems. ${ }^{18}$ Brookes' definition of bias relies on hypothetical equality of vote shares between two parties and the resulting seat differential observed. Given equal vote shares and uniform swing across geographic sub-units, whichever party obtains more seats is diagnosed as commanding a partisan bias. As such, it relies on the effectiveness of parties' geographic vote distribution securing seats in the parliament.

\footnotetext{
18 See Johnston $(1976,1992)$ for New Zealand, Johnston et al. (1998), Rossiter et al. (1997a, 1997b) for Great Britain.
} 
We hence evaluate bias in the Turkish election system by assuming a hypothetical equalvotes situation for the two largest parties. This translates into a systemic bias by yielding an unequal seat share for the parties involved. We apply the uniform swing to simulate the equal vote share distribution for the two largest parties. As such, each party's geographic electoral strength continues to be reflected in their new level of votes. The smaller (larger) of the two parties that receive (loose) votes due to uniform swing gains (loses) more in those districts that comprise a larger share in its overall vote than in other districts where it wins a lesser share of its countrywide votes. All details of the calculations for the simulated provincial election results across status quo and three alternative apportionment methods are given in Table A1 and Table A2 in the appendix. For an in-depth discussion of the three apportionment methods (Jefferson, Hamilton, Webster), the reader is referred to Young (1995).

Table 1 below presents seat distributions under different apportionment methods for 2002 and 2007 with and without a $10 \%$ threshold. ${ }^{19}$ For both of these elections when the threshold is lifted a number of parties have a level of support that allows them to win seats in the TBMM. For the three elections in 2011 and 2015 however, there are no such parties, and hence the 10\% threshold is ineffective in determining seat distribution. ${ }^{\mathbf{2 0}}$

\footnotetext{
19 The simulated seat distributions in Tables $1, \mathrm{~A} 1$ and A2 rely on seat numbers which have been calculated in each one of the 85 provinces/electoral districts according to different apportionment methods. Then in each election, vote counts are used to allot the seats to parties using the D'Hondt method. In the ensuing partisan bias calculations, top two parties' votes are equalized and provincial results are created applying uniform swing and then the D'Hondt method is applied to determine the seat distribution across parties.

${ }^{20}$ Table $\mathrm{A} 2$ in the appendix provide in its first column seat distributions under different apportionment methods without any simulated vote distributions across provinces that can be used in comparison with the results presented in Table 1.
} 
Table 1. Impact of apportionment method changes, 2002 and 2007 elections.

\begin{tabular}{|c|c|c|c|c|c|c|c|c|}
\hline \multirow[b]{3}{*}{ Type of Simulation } & \multicolumn{8}{|c|}{ ELECTION OF 3rd NOVEMBER, 2002} \\
\hline & \multicolumn{4}{|c|}{$\begin{array}{c}\text { Total Seat Count }=550 \\
10 \% \text { Threshold }\end{array}$} & \multicolumn{4}{|c|}{$\begin{array}{c}\text { Total Seat Count }=550, \\
\text { No Threshold }\end{array}$} \\
\hline & \multicolumn{4}{|c|}{ No Simulation } & \multicolumn{4}{|c|}{ No Simulation } \\
\hline $\begin{array}{l}\text { Apportionment } \\
\text { Method }\end{array}$ & $\begin{array}{l}\text { Status } \\
\text { Quo }\end{array}$ & Jefferson & Webster & Hamilton & $\begin{array}{l}\text { Status } \\
\text { Quo }\end{array}$ & Jefferson & Webster & Hamilton \\
\hline CHP & 178 & 184 & 182 & 183 & 116 & 116 & 115 & 115 \\
\hline MHP & 0 & 0 & 0 & 0 & 34 & 35 & 34 & 34 \\
\hline DEHAP & 0 & 0 & 0 & 0 & 51 & 46 & 47 & 48 \\
\hline AKP & 363 & 359 & 360 & 359 & 266 & 267 & 267 & 266 \\
\hline ANAP & 0 & 0 & 0 & 0 & 8 & 9 & 8 & 8 \\
\hline DYP & 0 & 0 & 0 & 0 & 43 & 43 & 45 & 45 \\
\hline GP & 0 & 0 & 0 & 0 & 28 & 31 & 30 & 30 \\
\hline Other Independents & 9 & 7 & 8 & 8 & 4 & 3 & 4 & 4 \\
\hline \multirow[t]{4}{*}{$\begin{array}{l}\text { Gallagher Index of } \\
\text { Disproportionality }\end{array}$} & 27.67 & 27.52 & 27.53 & 27.48 & 12.54 & 12.47 & 12.50 & 12.42 \\
\hline & \multicolumn{8}{|c|}{ ELECTION OF 22 JULY 2007} \\
\hline & \multicolumn{4}{|c|}{$\begin{array}{c}\text { Total Seat Count }=550, \\
10 \% \text { Threshold }\end{array}$} & \multicolumn{4}{|c|}{$\begin{array}{c}\text { Total Seat Count }=550, \\
\text { No Threshold }\end{array}$} \\
\hline & \multicolumn{4}{|c|}{ No Simulation } & \multicolumn{4}{|c|}{ No Simulation } \\
\hline $\begin{array}{l}\text { Apportionment } \\
\text { Method }\end{array}$ & $\begin{array}{l}\text { Status } \\
\text { Quo }\end{array}$ & Jefferson & Webster & Hamilton & $\begin{array}{c}\text { Status } \\
\text { Quo }\end{array}$ & Jefferson & Webster & Hamilton \\
\hline CHP & 112 & 121 & 120 & 119 & 106 & 114 & 112 & 111 \\
\hline MHP & 71 & 70 & 68 & 68 & 68 & 66 & 65 & 65 \\
\hline AKP & 341 & 334 & 334 & 335 & 327 & 316 & 316 & 317 \\
\hline SP & 0 & 0 & 0 & 0 & 1 & 3 & 3 & 3 \\
\hline DP & 0 & 0 & 0 & 0 & 8 & 13 & 13 & 13 \\
\hline GP & 0 & 0 & 0 & 0 & 5 & 6 & 6 & 6 \\
\hline Other Independents & 26 & 25 & 28 & 28 & 35 & 32 & 35 & 35 \\
\hline $\begin{array}{l}\text { Gallagher Index of } \\
\text { Disproportionality } \\
\end{array}$ & 12.0 & 11.3 & 11.3 & 11.4 & 10.1 & 8.5 & 8.6 & 8.7 \\
\hline
\end{tabular}

In 2002 when the $10 \%$ threshold is maintained, only AKP and CHP remain in the competition. We see that with the threshold in effect the AKP win is only slightly influenced by different seat distributions under different apportionment methods. When their votes are equalized using uniform swing, AKP obtains 15 to 20 more seats than $\mathrm{CHP}$ across different apportionment methods (see Table A1 in the appendix). If the present apportionment method is replaced by alternative apportionment methods, we observe a slight increase in the advantage 
of AKP margin over CHP. ${ }^{21}$ This is primarily due to the fact that AKP benefits in terms of seats in those larger provinces that gain from reapportionment more than it loses due equalization of the total vote shares of the two parties with a uniform swing. If, in other words, AKP were not to be competitive in larger metropolitan provinces, then its losses would have been larger under reapportioned seat distributions. The significant change is observed when the $10 \%$ threshold is lifted. Then in 2002 the AKP's winning majority disappears. Instead of getting 359 to 363 seats with the threshold in effect, the AKP seats are down to 266 to 267 range. ${ }^{22}$ The Kurdish Democratic People's Party (Demokratik Halk Partisi, DEHAP) emerges as the third largest party after the CHP, obtaining 46 to 51 seats under different appportionment methods.

The index of disproportionality improves significantly going down from 27.7 under the status quo apportionment to 12.5 . The improvements due to changing apportionment methods are negligibly small. The real improvement comes with the lifting of the $10 \%$ threshold. Our ensuing analyses will show that besides the seat-vote linkage that disproportionality index reflects changing apportionment methods leads to significant changes in the geographical composition of representation in the TBMM.

To evaluate the partisan bias, we have to compare the seat advantage for one of the top two parties whose votes are equalized in Table A1. We see that the AKP wins 15 to 20 more seats than the CHP even then their vote shares are equalized under four different apportionment methods. When the $10 \%$ threshold is lifted, we observe that the seat advantage of AKP actually rises from 15 to 27 seats under the status quo apportionment and it rises by a few seats across all alternative methods of apportionment. The GID is reduced by more than half. In other words, with $10 \%$ threshold lifted and apportionment method correcting the seat distributions to

\footnotetext{
${ }^{21}$ The status quo apportionment method distributes one seat to each province irrespective of population and then distributes the remaining seats according to the Hamilton method.

${ }^{22}$ In 2007 even when the $10 \%$ threshold is lifted the AKP still wins enough seats in the range of 316 to 327 out of a total of 550 seats to ensure a majority in the TBMM (see Table 1).
} 
correspond more directly to provincial populations, the whole party system becomes more proportional compared to the application of the threshold. However, after lifting the $10 \%$ threshold, the partisan bias favoring AKP rises slightly reaching 3.6 to $4.9 \%$ (20 to 27 seats) of the parliamentary size in 2002 (see Fig. 4). This is also due to the fact that when the threshold is lifted the new competition that wins seats in the TBMM actually hurts CHP seats more than AKP seats.

A similar, but less pronounced effect lifting the threshold is obtained in 2007 as well. It is clear from all our simulations and apportionment calculations that the presently used status quo system results in the highest biases favoring AKP. As Fig. 4 shows, this bias was highest in 2007 with 47 seats (8.5\% of the TBMM seats). The lowest bias was in November 2015 (26 seats or $4.7 \%$ of the TBMM seats) and 2002 elections (27 seats or $4.9 \%$ of the TBMM seats). ${ }^{23}$ We see from this figure that the presently used apportionment method inflates the partisan bias significantly. However, even when the apportionment bias is corrected we still see an inherent partisan bias that favors the ruling AKP in the 2002 to 2011 period. As the AKP loses some of its support base in the two 2015 elections we observe that the bias is significantly reduced under alternative apportionment methods. However, it still provides 26 to 28 seat advantage under the status quo apportionment system and hence provides high protection for the AKP's tenure as it did in its initial election of success in 2002.

How would the partisan bias change if the size of the TBMM was raised to 600 instead of 550 seats? The answer to this question depends on whether the $10 \%$ threshold is lifted or whether all parties that can effectively win seats in different provinces manage to go above the threshold. Therefore we calculated the partisan bias under the status quo apportionment system

\footnotetext{
${ }^{23}$ Given the average votes required for a seat in the TBMM reported in Fig. 1 in Section 2, these seat differentials maintained within the same apportionment and the election system actually correspond to approximately 2.9 million votes in 2002, 5.0 million votes in 2007, 4.3 million in 2011 and 3.4 million votes in 2015 elections.
} 
for the elections of 2011, June 2015 and November 2015. In these last three elections there were no parties that remained outside the TBMM although they could have won seats if the $10 \%$ threshold had been lifted. We see that the partisan bias favoring the AKP is slightly reduced to 33 (from 37) seats in 2011 and remains the same for the November 2015 election. However, for June 2015, if the TBMM had 600 seats, the bias favoring AKP would rise to 35 (from 28) seats. The specific geographic distribution of the electoral support for AKP which renders it competitive in both the larger metropolitan as well as the smaller Anatolian provinces creates an inherent advantage that continues under a larger parliament size of 600 seats.

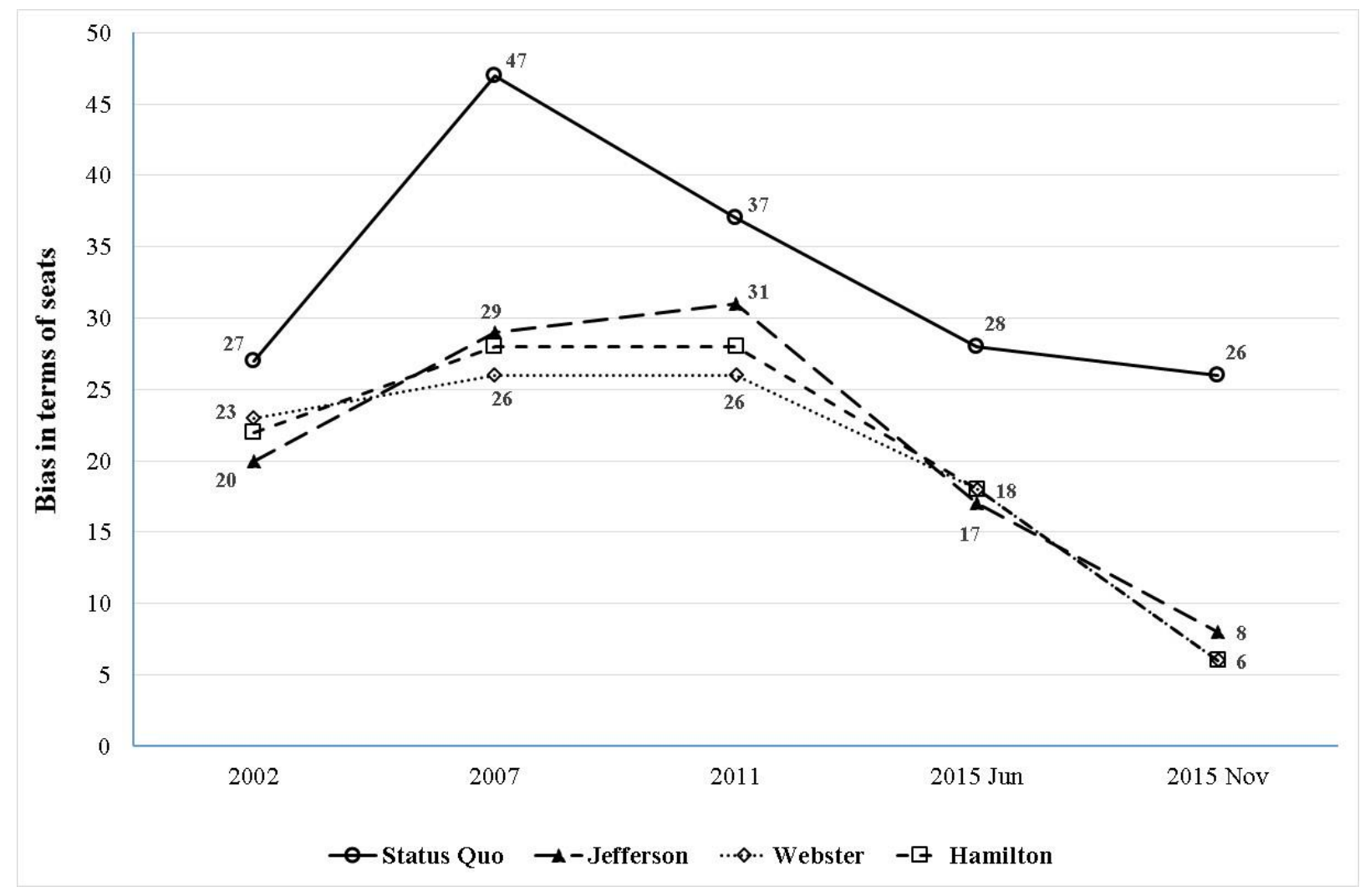

Fig. 4. Partisan bias in favor of AKP in terms of seats within a parliament size of 550 without the $10 \%$ threshold.

An important point that remains hidden in the details of our analysis concerns the influence of changing the apportionment method from the currently applied procedure to either one of the three alternatives. What is at stake in the currently applied procedure is the allocation 
of one seat for each one of the 81 provinces irrespective of their population. The remaining (550 $-81=469)$ seats are then allocated according to the seat equivalent share of the province within the total population. After the allocation of the integer part of the seat-equivalent population share, the undistributed seats are distributed from the largest quotient down. As such, several provinces that cannot get a single seat according to their population shares may end up with two seats, one from the first-round distribution and another from the seat quotient they possess.

The redistribution of seats using a straightforward Jefferson, Webster or Hamilton method instead of this two-round procedure, favors the larger western metropolitan provinces over smaller or newly created provinces. In order for these 81 seats to be distributed commensurately with population share, parties that are more competitive in those larger metropolitan provinces should benefit from the ultimate seat distribution simulations we undertake according to election results. However, we see that only a few seats shifted from status quo for instance in November 2015. CHP obtains a total of 134 seats under status quo, wins only 132 in Jefferson and 127 in Webster and Hamilton, respectively (Table A2). Note that these are net seat shifts. A total of 53 seats or $9.6 \%$ of the 550 seats in the TBMM are shifted between provinces. In fact, of the 81 provinces five suffer 2-seat losses and 43 suffer 1-seat loss. Seventeen provinces had an increase, and 17 had no change in their seat allocations. Of the 17 provinces that gain a seat or more, Istanbul gained 20, Ankara 7, İzmir 4, Antalya and Bursa 3 seats each. Table A1 and Table A2 report the resulting seats won by the parties either with their actual votes or with simulated votes according to uniform swing which equates top two parties AKP and CHP. Again focusing on November 2015 election, the main opposition party CHP loses in 15 provinces, but it wins one seat in eight provinces, wins two seats in Istanbul's first election zone and three seats in Istanbul's third zone. The previous eight single-seat wins are observed in the following cities: Istanbul's second zone, Ankara's first zone, one each from Izmir's two election zones and one each from Adana, Antalya, Bursa, and Tekirdağ. In other words, with the 
exception of Ankara, CHP's seat wins are in the largest provinces of the west and coastal regions.

Where then are the losses observed? Since CHP's vote in November 2015 is already heavily dependent on western provincial support, 1-seat losses occur in the central, eastern and southeastern provinces of Niğde, Sivas, Ardahan, and Tunceli. The other eleven provinces where CHP endures 1-seat losses are in western and coastal regions of the country. In other words, for CHP the real consequence is not a significant win or loss of seats. Neither is it a regional shift in CHP's representatives in the TBMM. It is the weight of the six metropolitan provinces Istanbul, Ankara, İzmir, Bursa, Adana and Antalya that increases within the CHP parliamentary group.

Another important consequence relates to the way small Anatolian provinces are being represented in the TBMM. Instead of having representatives from two largest parties, they will predominantly be represented by the single most significant party, namely AKP. Among the 15 provinces where CHP loses one seat, in only two (Çanakkale and Kırklareli) CHP continues to have one seat. In the remaining 13 provinces, all available seats are seized by the dominant AKP. AKP loses three of its total 317 seats-in 25 provinces it loses one seat and in two provinces two seats. Not surprisingly, AKP losses all occur in small Anatolian provinces and gains mainly in larger metropolitan provinces like Ankara, Istanbul, and İzmir. However, since AKP has strong electoral support in eastern and southeastern provinces as well, it gains two seats from Gaziantep and one each from Diyarbakır and Şanlıurfa. In other words, similar to $\mathrm{CHP}$, for AKP as well, the overall impact of changes in apportionment is not in terms of net wins or losses in the parliament, but instead in the composition of the parliament. Considering the higher level of its support and more nationalized geographic spread of its votes, the new seat distribution of AKP is not as much concentrated in a given region as that of CHP. On the 
other hand, when more seats are reserved for the larger metropolitan provinces, the AKP group in the parliament will also be more heavily composed of representatives from those provinces.

\subsection{Factors Influencing the Partisan Bias}

In order to test our expectations about the effect of changing the apportionment method, we can use the gains and losses of seats by parties across provinces under different apportionment methods as our dependent variable and try to explain the variation in this variable by looking into party system and socio-economic characteristics.

Fig. 5 below shows the geographic distribution of seat gains and losses for the exemplary case of November 2015 comparing the status quo apportionment with Hamilton and Webster methods which incidentally lead to precisely the same results. The lightest shaded provinces are those that either did not lose any seats or those that lost one seat. The two darker shades are in those provinces that gain either one seat or two or larger number of seats by merely moving from the status quo apportionment method to either Hamilton or Webster methods. We see that the largest gains occurred in places like Istanbul, Ankara, Izmir, Bursa, Kocaeli and Antalya. Those provinces that gain seats form a contiguous line starting from Diyarbakır in the southeast and moving towards the west into Şanlıurfa, Gaziantep, Hatay, Adana, İçel and Konya that is tied to Ankara in the north and Antalya in the south. From the capitol Ankara towards the west again we see that Bursa, Kocaeli, Istanbul and Tekirdağ form another cluster of adjacent provinces that gain seats along the Marmara Sea. On the Aegean coast Izmir and its neighboring eastern province Manisa are the two provinces that gain seats. Seat losses are concentrated in provinces of Black Sea coast, eastern and inner Anatolia regions. 


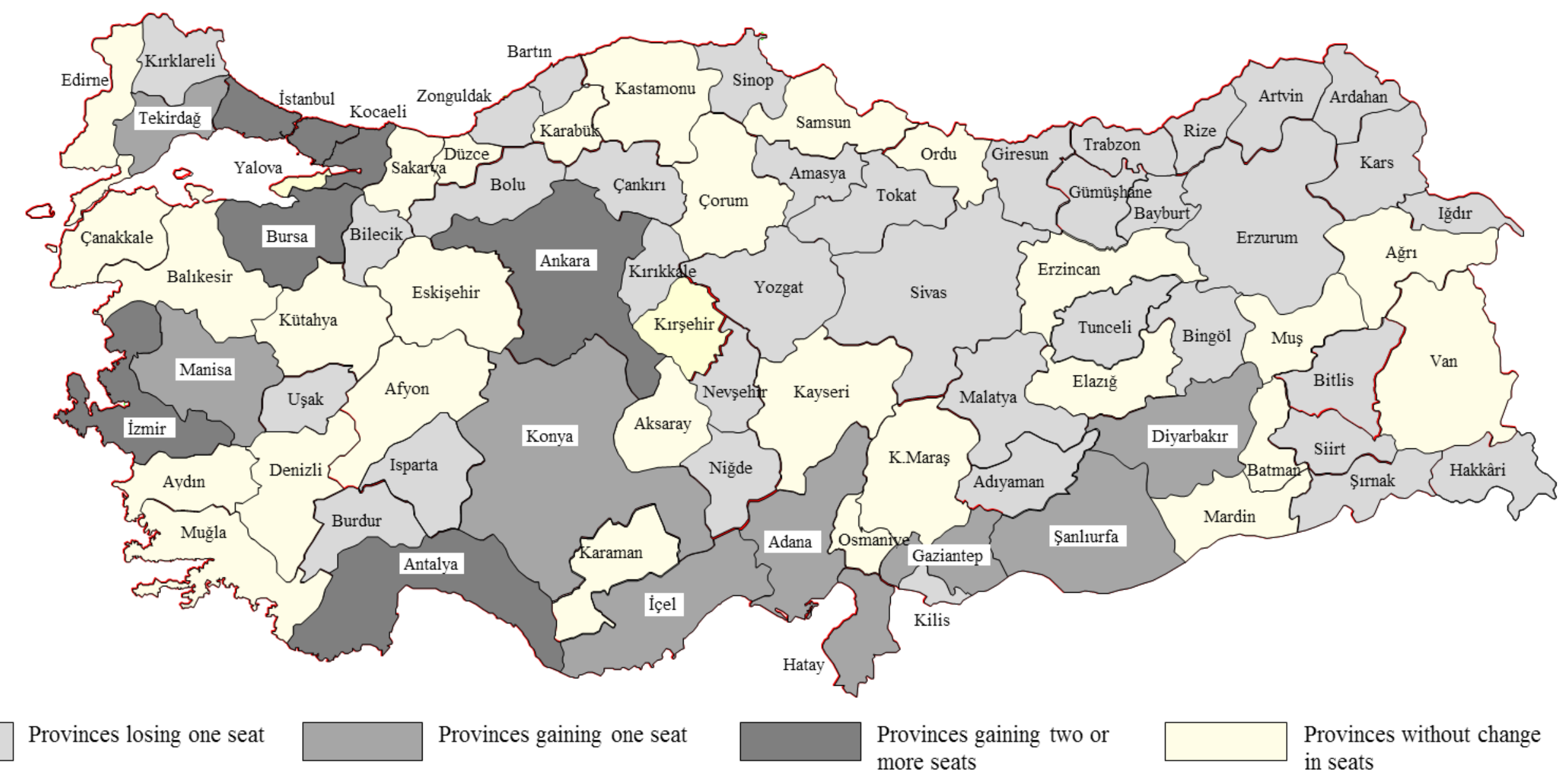

Fig. 5. Provinces gaining or losing seats when the status quo in seat apportionment is altered according to Webster method in November 2015 elections. 
Table 2. Determinants of changes in seats allocated to provinces by different apportionment methods, 2002-2015 pooled.*

\begin{tabular}{|c|c|c|c|c|c|c|c|c|c|}
\hline & \multirow{2}{*}{\multicolumn{3}{|c|}{ Jefferson }} & \multirow{2}{*}{\multicolumn{3}{|c|}{ Webster }} & \multirow{2}{*}{\multicolumn{3}{|c|}{ Hamilton }} \\
\hline & & & & & & & & & \\
\hline & B & Beta & Sig. & B & Beta & Sig. & B & Beta & Sig. \\
\hline Constant & -1.28 & & 0.68 & -1.51 & & 0.51 & -1.38 & & 0.56 \\
\hline Volatility & -0.05 & -0.26 & 0.00 & -0.03 & -0.24 & $\mathbf{0 . 0 0}$ & -0.03 & -0.23 & 0.00 \\
\hline Participation rate (\%) & 3.73 & 0.06 & 0.30 & 3.15 & 0.07 & 0.23 & 3.02 & 0.07 & 0.26 \\
\hline Effective number of parties & 0.28 & 0.11 & 0.09 & 0.22 & 0.11 & 0.06 & 0.22 & 0.11 & 0.08 \\
\hline $\begin{array}{l}\text { Agricultural sector per } \\
\text { capita }\end{array}$ & -0.85 & -0.36 & 0.00 & -0.55 & -0.33 & $\mathbf{0 . 0 0}$ & -0.56 & -0.32 & 0.00 \\
\hline GDP per capita & 0.00 & -0.06 & 0.25 & 0.00 & -0.07 & 0.16 & 0.00 & -0.07 & 0.16 \\
\hline Adjusted $R^{2}$ & 0.10 & & & 0.08 & & & 0.08 & & \\
\hline Std. Error of the Estimate & 2.85 & & & 2.09 & & & 2.14 & & \\
\hline
\end{tabular}

* Beta column refers to standardized beta coefficients, Sig. the column refers to the significance level.

At the provincial level, we already have party system measures of volatility, effective number of parties and participation. For the socio-economic characteristics of the provinces throughout five elections in the period of 2002-2015, we use the provincial sectoral breakdown of the Gross Domestic Product (GDP) by the Turkish Statistical Institute (Türkiye Istatistik Kurumu, TÜIK) for the 2004-2014 period. ${ }^{24}$ We extended the estimates by applying a simple linear trend line for each province to cover the years 2002, 2003 and 2015. Table 2 presents estimates of the influence from provincial characteristics upon changes of seats allocated to provinces for the three apportionment methods we used in our analyses. ${ }^{\mathbf{2 5}}$

\footnotetext{
${ }^{24}$ For provincial GDP data, see the web page of TÜIK (The Turkish Statistical Institute) at the URL address http://www.turkstat.gov.tr/UstMenu.do?metod=temelist (retrieved in February 2018).

${ }^{25}$ Cells that contain statistically significant findings at the conventional 5\% level are bolded. To check for multicollinearity in these estimations, we obtained variance inflation factor $(V I F)$ scores which remained between 1.05 and 2.2 indicating no serious problem.
} 
We see that instead of the overall level of per capita economic activity it is the agricultural sector activity level that shapes the seat allocations by different apportionment methods; as the provincial agricultural sector GDP rises, the number of seats allocated under alternative apportionment methods declines from the presently used (status quo) apportionment method allocations. In other words, the alternative apportionment methods appear to favor provinces where lower agricultural sector activity is present. Similarly, provinces with the relatively higher level of party competition reflected in their higher effective number of parties and those with more stable electoral preferences (or lower volatility) appear to gain more seats compared to the presently used apportionment method. Provincial participation rate which can be taken to reflect an interest in politics or partisan mobilization effects does not have a significant coefficient.

When the same analysis is conducted for the seats won by AKP, CHP, MHP and the Kurdish parties across all elections during the 2002-2015 period, we observe the same results under different apportionment methods with both electoral volatility and agricultural GDP per capita having negative and significant coefficients. In addition, for the CHP we also observe that the overall level of GDP is also statistically significant. For the Kurdish parties in addition to volatility and agricultural GDP we also observe the effective number of parties having a significant and positive coefficient. In other words, as the level of party competition rises across provinces the Kurdish parties' tendency to win additional seats under new apportionment methods also rises. This is primarily due to the fact that additional seats are allocated in larger provinces where according to the D'Hondt system smaller parties get a higher chance of winning seats as the number of seats allocated grows. 


\section{Conclusion}

Our analyses revealed several diagnoses that are significant for both the specifics of Turkish politics and the phenomenon of partisan bias in proportional representation systems that is worthy of note for the establishment of predominant party systems. Our analyses trace the development of disproportionality in the Turkish election system. The apportionment system has worked for the benefit of the relatively more developed western provinces of Turkey for the eight elections in the 1950-1977 period. The smaller eastern and southeastern provinces were disadvantaged in terms of seats allocated for their representation in the parliament. The Kurdish population dominated provinces form a sub-group of 16 provinces in the eastern and southeastern Anatolia region. Our analysis suggest that these provinces were significantly disadvantaged in only four of the eight elections in the 1950-1977 period. Although these provinces had significantly higher population figures per seat available, the magnitude of this excess population figures in these years was only between 6 to $9 \%$ higher compared to the rest of the provinces. The 1980 military regime changed these dynamics in an unexpected way and rendered these relatively small eastern and southeastern provinces more advantageous compared to the western metropolitan centers. The population per seat available in the 16 provinces with $40 \%$ or higher Kurdish population shares remained lower, but their difference from the rest of the provinces throughout the post-1980 period is statistically insignificant. The provinces with smaller population shares had a significantly lower population per seat available in the same period.

Dynamics behind this change is mostly speculative. From the perspective of apportionment alone, it is clear that metropolitan areas suffered under the new regime of representation, but at the same time the eastern and southeastern provinces with sizeable Kurdish population had disproportionate representation with respect to their population share. It seems that the military regime, having the experience of the late 1970s in mind, valued the 
fact that relatively more progressive and left-leaning metropolitan areas remaining underrepresented would favor their political vision for the future of the country. Kurdish provinces in Eastern and Southeastern Anatolia having over-representation came to be of critical importance only more than three decades later in 2015 . This might be treated as a rationalization for the military regime's willingness to create such a clear bias disfavoring western metropolitan areas. As a result, Turkish politics of the post-1980 period remained unduly dominated by smaller Anatolian conservative constituencies that are over-represented just due to the apportionment method in use. The Kurdish left-leaning Peoples' Democratic Party (Halkların Demokratik Partisi, HDP) used this to its advantage in 2015 so that it was able to surpass the Turkish nationalist group in the TBMM with the electoral support that was lower than theirs.

Our analyses suggest that the present apportionment method created an advantageous position for the largest party of the 2002 to 2015 period. If the apportionment method and the $10 \%$ threshold were not in use in 2002, AKP could not possibly form a single party government. Due to path-dependent dynamics put in motion, the electoral undercurrents in the elections that followed are difficult to evaluate. The expectations of the system in place clearly move the electoral support behind the existing larger parties. We see that both in 2007 and 2011 the ruling AKP wins a clear majority under all alternative apportionment methods with or without the $10 \%$ threshold. The endogeneity of strategic electoral preferences is most likely to have kept the potential opposition away from competition and hence creating the advantageous competitive arena for the largest party in the system.

In addition to the $10 \%$ threshold, we also diagnose a significant degree of bias in the system in favor of AKP. We see that even if the two most important parties were to receive on the aggregate an equal number of votes, the constellation of the geographic distribution of the AKP support creates 26 to 47 seats in favor of the ruling party. These seat biases correspond to 
approximately 2.9 to 5 million votes of advantage for the favored AKP. Among 41.4 to 56.9 million registered voters in the 2002 to 2015 period, such levels of bias are not trivial.

The impact of shifting seats due to changing apportionment systems across provinces is reflected not in the total net number of seats that parties get as a result, but rather in the composition of their parliamentary groups. We see that in the AKP as well as CHP the weight amongst the respective TBMM groups of the larger western metropolitan provinces rises. From the perspective of the smaller Anatolian provinces, we observe that their representation will be more heavily taken over by the larger AKP. As the seats of these smaller provinces are reduced due to apportionment system changes, the smaller party (that is a party other than the AKP) loses that seat and hence the representation of the province becomes dominated by the single larger party of the system (which is the AKP). In other words, the opposition in the system will hence be taken over predominantly by the representatives of the larger metropolitan provinces. However, even amongst the AKP group of parliamentarians the share of those from the larger western metropolitan provinces appear to rise.

The significance of these shifts in the representation system should not be underemphasized. The rise of the conservative tide, to use Çarkoğlu and Kalaycioğlu's (2009) terminology, in Turkish politics might to a large extent be due to this over-representation of the smaller Anatolian provinces in the representation system and due to the inherent bias that favors the AKP. Thus, an election reform that corrects these representational biases will not only be aimed to restore the one-man-one-vote principle and the constitutional equity amongst voters and parties, but is also expected in a sense to contribute to the correction of the conservative representational bias in the country.

The formidable electoral performance of the AKP in its early phase was the making of not only a shift in voter preferences. In addition, the $10 \%$ threshold helped keep the competition away from representation and the apportionment methods gave the conservative constituencies 
of the smaller Anatolian provinces undue representation solidifying the ruling party's ideological stances. Moreover, the inherent partisan bias in the system added an extra push behind AKP representation that ranged between 4.7 to $8.5 \%$ seat bias in the 550-seat TBMM. The creation of a predominant or a hegemonic party is hence at least partially due to these electoral system biases that favored the larger party. Turkish experience clearly shows the critical role that the electoral system and biases therein play in the establishment of a predominant party system.

Our research suggests that the partisan bias and the apportionment system created an opportunity for the AKP to first capture the executive office with a comfortable majority disproportional to its electoral support and helped create a dynamic that facilitated the maintenance of its electoral dominance over the following four elections. Given the democratic backsliding that gained momentum after the twin elections in 2015 and the failed coup attempt in July 2016, such partisan and apportionment biases may not be sufficient, but appear to be necessary conditions behind the rising tendency towards electoral authoritarianism.

The critical constitutional referendum of April 2017 and the presidential and parliamentary elections of June 2018 were both held under a state of emergency imposed after the failed coup attempt in July 2016. The existence of a level playing field in these elections are questionable at best. Our findings show the systemic precursors to these developments and call for continued research in other country settings where electoral authoritarianism is on the rise. 


\section{Appendix}

Table A1. Partisan bias with and without 10\% threshold for 2002 and 2007 elections.

\begin{tabular}{|c|c|c|c|c|c|c|c|c|}
\hline \multirow{4}{*}{$\begin{array}{l} \\
\text { Type of Simulation } \\
\text { Apportionment }\end{array}$} & \multicolumn{8}{|c|}{ ELECTIONS OF 03 NOVEMBER 2002} \\
\hline & \multicolumn{4}{|c|}{$\begin{array}{c}\text { Total Seat Count }=550 \\
10 \% \text { Threshold }\end{array}$} & \multicolumn{4}{|c|}{$\begin{array}{c}\text { Total Seat Count }=550 \\
\text { No Threshold }\end{array}$} \\
\hline & \multicolumn{4}{|c|}{ Top Two Winners Equal Votes } & \multicolumn{4}{|c|}{ Top Two Winners Equal Votes } \\
\hline & $\begin{array}{l}\text { Status } \\
\text { Quo }\end{array}$ & Jefferson & Webster & Hamilton & $\begin{array}{c}\text { Status } \\
\text { Quo }\end{array}$ & Jefferson & Webster & Hamilton \\
\hline CHP & 262 & 262 & 261 & 261 & 177 & 183 & 181 & 182 \\
\hline MHP & 0 & 0 & 0 & 0 & 37 & 35 & 34 & 34 \\
\hline DEHAP & 0 & 0 & 0 & 0 & 50 & 47 & 48 & 48 \\
\hline $\mathrm{AKP}$ & 277 & 281 & 281 & 281 & 204 & 203 & 204 & 204 \\
\hline ANAP & 0 & 0 & 0 & 0 & 8 & 9 & 9 & 9 \\
\hline DYP & 0 & 0 & 0 & 0 & 44 & 40 & 41 & 40 \\
\hline GP & 0 & 0 & 0 & 0 & 26 & 30 & 29 & 29 \\
\hline Independents & 11 & 7 & 8 & 8 & 4 & 3 & 4 & 4 \\
\hline $\begin{array}{l}\text { Gallagher Index of } \\
\text { Disproportionality }\end{array}$ & 25.3 & 25.7 & 25.6 & 25.6 & 9.6 & 9.8 & 9.8 & 9.9 \\
\hline $\begin{array}{l}\text { Difference between } \\
\text { top two parties }\end{array}$ & 15 & 19 & 20 & 20 & 27 & 20 & 23 & 22 \\
\hline $\begin{array}{l}\text { Relative Bias } \\
\text { with respect to } \\
\text { Parliament Size }\end{array}$ & $2.7 \%$ & $3.5 \%$ & $3.6 \%$ & $3.6 \%$ & $4.9 \%$ & $3.6 \%$ & $4.2 \%$ & $4.0 \%$ \\
\hline
\end{tabular}

\section{ELECTIONS OF 22 JULY 2007}

\begin{tabular}{|c|c|c|c|c|c|c|c|c|}
\hline \multirow{3}{*}{$\begin{array}{l}\text { Type of Simulation } \\
\text { Apportionment } \\
\text { Method }\end{array}$} & \multicolumn{4}{|c|}{$\begin{array}{c}\text { Total Seat Count }=550 \\
10 \% \text { Threshold }\end{array}$} & \multicolumn{4}{|c|}{$\begin{array}{l}\text { Total Seat Count }=550, \\
\text { No Threshold }\end{array}$} \\
\hline & \multicolumn{4}{|c|}{ Top Two Winners Equal Votes } & \multicolumn{4}{|c|}{ Top Two Winners Equal Votes } \\
\hline & $\begin{array}{c}\text { Status } \\
\text { Quo }\end{array}$ & Jefferson & Webster & Hamilton & $\begin{array}{c}\text { Status } \\
\text { Quo }\end{array}$ & Jefferson & Webster & Hamilton \\
\hline CHP & 199 & 207 & 211 & 210 & 191 & 199 & 201 & 200 \\
\hline MHP & 73 & 70 & 67 & 68 & 67 & 64 & 66 & 66 \\
\hline AKP & 244 & 239 & 237 & 237 & 238 & 228 & 227 & 228 \\
\hline SP & 0 & 0 & 0 & 0 & 2 & 4 & 3 & 3 \\
\hline DP & 0 & 0 & 0 & 0 & 9 & 11 & 11 & 11 \\
\hline GP & 0 & 0 & 0 & 0 & 5 & 6 & 5 & 5 \\
\hline $\begin{array}{r}\text { Kurdish \& } \\
\text { Other } \\
\text { Independents } \\
\end{array}$ & 34 & 34 & 35 & 35 & 38 & 38 & 37 & 37 \\
\hline $\begin{array}{l}\text { Gallagher Index of } \\
\text { Disproportionality }\end{array}$ & 12.0 & 13.1 & 13.6 & 13.5 & 10.9 & 12.1 & 12.4 & 12.2 \\
\hline $\begin{array}{l}\text { Difference between } \\
\text { top two parties }\end{array}$ & 45 & 32 & 26 & 27 & 47 & 29 & 26 & 28 \\
\hline $\begin{array}{l}\text { Relative Bias } \\
\text { with respect to } \\
\text { Parliament Size }\end{array}$ & $8.2 \%$ & $5.8 \%$ & $4.7 \%$ & $4.9 \%$ & $8.5 \%$ & $5.3 \%$ & $4.7 \%$ & $5.1 \%$ \\
\hline
\end{tabular}


Table A2. Partisan Bias with and without 10\% threshold for 2011 and 2015 elections.

\section{ELECTIONS OF 12 JUNE 2011}

\begin{tabular}{|c|c|c|c|c|c|c|c|c|}
\hline Type of Simulation & \multicolumn{4}{|c|}{ No Simulation } & \multicolumn{4}{|c|}{ Top Two Winners Equal Votes } \\
\hline Apportionment Method & $\begin{array}{c}\text { Status } \\
\text { Quo }\end{array}$ & Jefferson & Webster & Hamilton & $\begin{array}{c}\text { Status } \\
\text { Quo }\end{array}$ & Jefferson & Webster & Hamilton \\
\hline $\mathrm{CHP}$ & 135 & 136 & 138 & 137 & 206 & 212 & 215 & 214 \\
\hline MHP & 53 & 51 & 53 & 53 & 56 & 54 & 53 & 53 \\
\hline Kurdish Independents & 35 & 34 & 32 & 32 & 45 & 41 & 41 & 41 \\
\hline $\mathrm{AKP}$ & 327 & 329 & 327 & 328 & 243 & 243 & 241 & 242 \\
\hline $\begin{array}{l}\text { Gallagher Index of } \\
\text { Disproportionality }\end{array}$ & 8.0 & 8.3 & 8.0 & 8.1 & 9.9 & 10.5 & 11.0 & 10.8 \\
\hline $\begin{array}{l}\text { Difference btw. top two } \\
\text { parties }\end{array}$ & 192 & 193 & 189 & 191 & 37 & 31 & 26 & 28 \\
\hline $\begin{array}{l}\text { Relative Bias with respect to } \\
\text { Parliament Size }\end{array}$ & $34.9 \%$ & $35.1 \%$ & $34.4 \%$ & $34.7 \%$ & $6.7 \%$ & $5.6 \%$ & $4.7 \%$ & $5.1 \%$ \\
\hline
\end{tabular}

\section{ELECTIONS OF 07 JUNE 2015}

\begin{tabular}{|c|c|c|c|c|c|c|c|c|}
\hline \multirow{2}{*}{$\begin{array}{l}\text { Type of Simulation } \\
\text { Apportionment Method }\end{array}$} & \multicolumn{4}{|c|}{ No Simulation } & \multicolumn{4}{|c|}{ Top Two Winners Equal Votes } \\
\hline & $\begin{array}{c}\text { Status } \\
\text { Quo }\end{array}$ & Jefferson & Webster & Hamilton & $\begin{array}{c}\text { Status } \\
\text { Quo }\end{array}$ & Jefferson & Webster & Hamilton \\
\hline $\mathrm{CHP}$ & 132 & 138 & 138 & 138 & 176 & 185 & 185 & 185 \\
\hline MHP & 80 & 81 & 80 & 80 & 86 & 81 & 79 & 79 \\
\hline HDP & 80 & 76 & 77 & 77 & 84 & 82 & 83 & 83 \\
\hline $\mathrm{AKP}$ & 258 & 255 & 255 & 255 & 204 & 202 & 203 & 203 \\
\hline $\begin{array}{l}\text { Gallagher Index of } \\
\text { Disproportionality }\end{array}$ & 5.7 & 5.3 & 5.3 & 5.3 & 6.8 & 7.8 & 7.8 & 7.8 \\
\hline $\begin{array}{l}\text { Difference btw. top two } \\
\text { parties }\end{array}$ & 126 & 117 & 117 & 117 & 28 & 17 & 18 & 18 \\
\hline \multirow[t]{2}{*}{$\begin{array}{l}\text { Relative Bias with respect to } \\
\text { Parliament Size }\end{array}$} & $22.9 \%$ & $21.3 \%$ & $21.3 \%$ & $21.3 \%$ & $5.1 \%$ & $3.1 \%$ & $3.3 \%$ & $3.3 \%$ \\
\hline & \multicolumn{8}{|c|}{ ELECTIONS OF 01 NOVEMBER 2015} \\
\hline Type of Simulation & \multicolumn{4}{|c|}{ No Simulation } & \multicolumn{4}{|c|}{ Top Two Winners Equal Votes } \\
\hline Apportionment Method & $\begin{array}{l}\text { Status } \\
\text { Quo }\end{array}$ & Jefferson & Webster & Hamilton & $\begin{array}{c}\text { Status } \\
\text { Quo }\end{array}$ & Jefferson & Webster & Hamilton \\
\hline CHP & 134 & 132 & 127 & 127 & 209 & 216 & 217 & 217 \\
\hline MHP & 40 & 44 & 43 & 43 & 44 & 46 & 45 & 45 \\
\hline HDP & 59 & 60 & 61 & 61 & 62 & 64 & 65 & 65 \\
\hline $\mathrm{AKP}$ & 317 & 314 & 319 & 319 & 235 & 224 & 223 & 223 \\
\hline $\begin{array}{l}\text { Gallagher Index of } \\
\text { Disproportionality }\end{array}$ & 6.9 & 6.4 & 7.1 & 7.1 & 10.7 & 12.1 & 12.3 & 12.3 \\
\hline $\begin{array}{l}\text { Difference btw. top two } \\
\text { parties }\end{array}$ & 183 & 182 & 192 & 192 & 26 & 8 & 6 & 6 \\
\hline $\begin{array}{l}\text { Relative Bias with respect to } \\
\text { Parliament Size }\end{array}$ & $33.3 \%$ & $33.1 \%$ & $34.9 \%$ & $34.9 \%$ & $4.7 \%$ & $1.5 \%$ & $1.1 \%$ & $1.1 \%$ \\
\hline
\end{tabular}




\section{References}

Akkoyunlu, K., \& Öktem, K. (2016). Existential insecurity and the making of a weak authoritarian regime in Turkey. Southeast European and Black Sea Studies, 16(4), 505-527.

Balinski, M. L., \& Young, H. P. (2010). Fair representation: meeting the ideal of one man, one vote. Brookings Institution Press.

Brookes, R. H. (1959). Electoral distortion in New Zealand. Australian Journal of Politics \& History, 5(2), 218-223.

Brookes, R. H. (1960). The analysis of distorted representation in two-party single-member elections. Political Science, 12(2), 158-167.

Çarkoğlu, A. (2002). "The Rise of the New Generation Pro-Islamists in Turkey: The Justice and Development Party Phenomenon in the November 2002 Elections in Turkey", South European Society \& Politics, 7(3), 123-156.

Çarkoğlu, A., \& Avc1, G. (2002). An analysis of the electorate from a geographical perspective. In Esmer, Y. and Sayar1, S. (Eds.), Politics, parties, and elections in Turkey. Lynne Rienner Publishers, $115-136$.

Çarkoğlu, A., \& Erdoğan, E. (1998). Fairness in the apportionment of seats in the Turkish legislature: is there room for improvement? New Perspectives on Turkey, 19, 97-124.

Çarkoğlu, A. \& Kalaycığlu. E. (2009). The Rising Tide of Conservatism in Turkey, Palgrave.

Çarkoğlu, A., \& Yıldırım, K. (2015). Election Storm in Turkey: What do the Results of June and November 2015 Elections Tell Us? Insight Turkey, 17(4), 57-79.

Cinar, K. (2016). Local determinants of an emerging electoral hegemony: The case of Justice and Development Party (AKP) in Turkey. Democratization, 23(7), 1216-1235.

Eroğul, C. (1990). Demokrat Parti: Tarihi ve İdeolojisi (Democrat Party: Its History and Ideology), in Turkish. Second Printing, İmge Yayınevi.

Esen, B., \& Gümüşçü, Ş. (2016). Rising competitive authoritarianism in Turkey. Third World Quarterly, 37(9), 1581-1606.

Farrel, D. M. (2011). Electoral Systems: A Comparative Introduction, 2nd Edition, Palgrave.

Gümüşcü, S. (2013). The emerging predominant party system in Turkey. Government and Opposition, $48(2), 223-244$.

Güvenç, M., \& Kirmanoğlu, H. (2009). Electoral Atlas of Turkey, 1950-2009. Istanbul Bilgi University Press.

Johnston, R. J. (1976). Spatial structure, plurality systems, and electoral bias. The Canadian Geographer/Le Géographe Canadien, 20(3), 310-328.

Johnston, R. J. (1992). Electoral geography. In: Holland, M. (Ed.), Electoral Behaviour in New Zealand. Oxford University Press, Auckland, pp. 25-50.

Johnston, R. J., Pattie, C. J., Rossiter, D. J., Dorling, D. F .L., Tunstall, H., \& MacAllister, I. (1998). Anatomy of a Labour landslide: the constituency system and the 1997 election. Parliamentary Affairs, 51(2), 131-148. 
Kalaycioğlu, E. (1994). Elections and party preferences in Turkey: Changes and continuities in the 1990s. Comparative Political Studies, 27(3), 402-424.

Mardin, Ş. (1973). Center-periphery relations: A key to Turkish politics?. Daedalus, 102(1), 169-190.

Morse, Y. L. (2012). The era of electoral authoritarianism. World Politics, 64(1), 161-198.

Mutlu, S. (1996). Ethnic Kurds in Turkey: a demographic study. International Journal of Middle East Studies, 28 (4), 517-541.

Pukelsheim, F. (2014). Proportional Representation. AMC, 10, 12.

Rae, D., Hanby, V., \& Loosemore, J. (1971). Thresholds of representation and thresholds of exclusion: An analytic note on electoral systems. Comparative Political Studies, 3(4), 479-488.

Rossiter, D. J., Johnston, R. J., \& Pattie, C. J. (1997a). Estimating the partisan impact of redistricting in Great Britain. British Journal of Political Science, 27(2), 319-331.

Rossiter, D. J., Johnston, R. J., \& Pattie, C. J. (1997b). Redistricting and electoral bias in Great Britain. British Journal of Political Science, 27(2), 466-472.

Sabuncu, Y. (2006). Seçim Barajları ve Siyasal Sonuçları (Election Thresholds and their Political Consequences), in Turkish. Anayasa Yargısı Dergisi, 23, pp.191-197.

Sartori, G. (1976). Parties and party systems: A framework for analysis. Cambridge: Cambridge University Press. Reprinted in 2005 in the ECPR Classics Series.

Schedler, A. (2013). The politics of uncertainty: Sustaining and subverting electoral authoritarianism. OUP Oxford.

Schuster, K., Pukelsheim, F., Drton, M., \& Draper, N. R. (2003). Seat biases of apportionment methods for proportional representation. Electoral Studies, 22(4), 651-676.

Schwingenschlögl, U., \& Drton, M. (2004). Seat allocation distributions and seat biases of stationary apportionment methods for proportional representation. Metrika, 60(2), 191-202.

Somer, M. (2016). Understanding Turkey's democratic breakdown: old vs. new and indigenous vs. global authoritarianism. Southeast European and Black Sea Studies, 16(4), 481-503.

Taagepera, R., \& Shugart, M. S. (1989). Seats and votes: The effects and determinants of electoral systems. Yale University Press.

Young, H. P. (1995). Equity: in theory and practice. Princeton, New Jersey, Princeton University Press. 